\title{
Working Time Society consensus statements: Evidence-based effects of shift work and non-standard working hours on workers, family and community
}

\author{
Anna ARLINGHAUS ${ }^{1 *}$, Philip BOHLE ${ }^{2}$, Irena ISKRA-GOLEC ${ }^{3}$, \\ Nicole JANSEN ${ }^{4}$, Sarah JAY ${ }^{5}$ and Lucia ROTENBERG ${ }^{6}$ \\ ${ }^{1}$ XIMES GmbH, Austria \\ ${ }^{2}$ Faculty of Health Sciences, The University of Sydney, Australia \\ ${ }^{3}$ Institute of Psychology, SWPS University of Social Sciences and Humanities, Poland \\ ${ }^{4}$ Department of Epidemiology, CAPHRI School for Public Health and Primary Care, Faculty of Health, \\ Medicine and Life Sciences, Maastricht University, The Netherlands \\ ${ }^{5}$ Appleton Institute, School of Health, Medical and Applied Sciences, CQUniversity, Australia \\ ${ }^{6}$ Laboratory of Environmental and Health Education, Oswaldo Cruz Institute, Brazil
}

Received after WTS symposium comments: September 13, 2017

Received after editors 'revisions: October 27, 2017

Received after external review: May 29, 2018

Received after expert panel (Final accepted): August 21, 2018

Published online in J-STAGE January 31, 2019

\begin{abstract}
Working time arrangements that require shift work or other non-standard working hours have significant potential to encroach on time that is highly valued for family, social and leisure activity. This can often result in workers experiencing poorer work-family or work-life balance. Based on an extensive literature search and expert knowledge, primary risk factors were identified including shift work; long, irregular and unpredictable working hours; and work on evenings and weekends (in combination and independent of shift work). On the other hand, flexibility, in the form of adequate worker control over work schedules, may be a protective factor. In addition, workers experiencing excessive work-life conflict are likely to reduce their working hours, reflecting a reciprocal relationship between working hours and work-life balance. Workers' families are also affected by shift work and non-standard working hours. Parents' shift work is associated with poorer emotional and developmental outcomes for their children, and to a greater likelihood of risky behavior in adolescence. Additionally, the risk of separation or divorce is increased, especially for parents working night shifts. Due to relationships such as those above, the consequences of shiftwork and non-standard working hours on family and social life are largely dependent on a complex interaction between specific work schedules, other aspects of work organization, and family and individual worker characteristics. This article provides an overview of current evidence regarding the relationships between working time arrangements and various social and family variables, and concludes with shift scheduling and intervention recommendations to improve work-life balance and social well-being.
\end{abstract}

Key words: Shift work, Working hours, Work-life balance, Work-family balance, Social participation, Review

\footnotetext{
*To whom correspondence should be addressed.

E-mail: arlinghaus@ximes.com
}

(C)2019 National Institute of Occupational Safety and Health 


\section{Consensus Statements}

1) Specific characteristics of work schedules interact in complex ways with individual factors, such as family arrangements, precluding the formulation of general or universal recommendations. However, some general principles can be derived from empirical evidence:

a. Non-standard working hours, such as night work, long hours, irregular and unpredictable hours, work on evenings and weekends are commonly associated with reduced social and family well-being.

b. Adequate worker 'control' over working hours can be a significant protective factor in reducing work-life or work-family conflict.

2) Until now, most studies on the relationship between working time arrangements and work-life balance have relied on cross-sectional designs. Their findings do not provide adequate evidence of causality and should therefore be interpreted with caution. More prospective and intervention studies, specifically in the areas of overtime, on-call work, remote work, and reciprocal relations between working time arrangements and work-life or workfamily conflict, are required to extend our understanding of the causal impact of working time arrangements on workers, family and community.

3) Existing work schedules can often be modified to enhance their social effects. Intervention strategies should therefore primarily target

a. improvements in work scheduling to minimize social impairments,

b. ensuring adequate remuneration,

c. providing sufficient child care and support for workers (and their families) engaged in shift work or schedules requiring irregular or socially undesirable hours.

More detailed clinical recommendations and intervention strategies can be found in this article.

4) Where shift schedules are difficult to redesign, supplementary mitigation strategies (which minimize the harm associated with the specific schedule), such as training and education of workers and employers, should be developed in partnership with employees or their representatives.

Consensus statements review expert panel: Imelda WONG ${ }^{1}$ (Chair), Debby BECKERS ${ }^{2}$, Philip TUCKER ${ }^{3}$

${ }^{1}$ National Institute for Occupational Safety and Health, USA

${ }^{2}$ Radboud University, Netherlands

${ }^{3}$ Swansea University, UK

Full consensus among panel members on all statements.

\section{Introduction}

This manuscript is part of a series of consensus papers developed by the Working Time Society, commissioned by the International Commission on Occupational Health $^{1)}$. The goal of this series is to provide guidance for a broad, international audience of researchers, industry members, workers, labor representatives, policy makers, and other interested stakeholders on managing fatigue associated with nonstandard working hours and ensuring worker health and safety. They describe the current state of research, identify health and safety risks and make recommendations for effective interventions, and suggest future research directions. Each paper is accompanied by a number of consensus statements, developed through the procedures outlined in Wong et al ${ }^{1}$.

An interdisciplinary author group with strong expertise in the field of working hour research was assembled to describe the state of the art knowledge on shift work and non-standard working hours in relation to social effects. Since the aim was not to provide a systematic review or a meta-analysis, the literature was reviewed nonsystematically by a thorough search in different scientific databases (e.g., PubMed, Google Scholar) and as far as possible only high quality studies were included in the review. Examples are peer-reviewed studies using case- 
control design, cohort studies, intervention studies and population-based epidemiological research. Additionally, other publications known to the authors (e.g. white papers, books) were included where it fit. In some cases where no or very few high quality studies were found, limitations of the studies cited are discussed in the text. The content of this consensus paper underwent a thorough discussion and consensus process including a multilevel and multistage review process within the Working Time Society to ensure a broad consensus about the content ${ }^{1)}$.

\section{Working Time Arrangements, Social Rhythms and Work-family Balance}

There is no standard or single definition of "shift work". This consensus report adopts the definition proposed by $\operatorname{Costa}^{2}$, which describes shift work as any form of work organization, different from the normal "daily work", in which the operating time of a company is extended beyond the usual $8-9 \mathrm{~h}$ to cover the entire $24 \mathrm{~h}$, through the alternation of different groups of workers. Shift work therefore involves work hours outside typical or "standard" working hours, which are usually defined as Monday to Friday, between approximately $08: 00$ and 17:00 or $18: 00 \mathrm{~h}^{2}$. So called "non-standard" working hours can be associated with shift work but also exist independently from it, and include long, irregular and unpredictable hours; work on evenings, nights and weekends; and on-call work or standby duties ${ }^{2)}$. Despite their name, "non-standard" working hours are in fact very common. For example, in the European Union in 2015, 26.6\% of all employed persons usually worked on Saturdays, $14.5 \%$ usually worked on Sundays, and $16 \%$ regularly worked in the evening ${ }^{3-5}$.

Non-standard hours are the result of flexible production requirements, extended service hours, and incentives to extract maximum output from expensive plants and equipment. Advances in information and communication technologies (e.g., mobile computers and smartphones) also allow some forms of work to be done almost anywhere and at any time. The associated "supplemental work" leads to extended work hours and is, by definition, linked to a higher frequency of work at 'non-standard' times ${ }^{6}$.

While the interference of shift work with biological rhythms and its implications are described elsewhere ${ }^{7)}$, this paper examines associations between working time arrangements and a range of family and social outcomes. Various terms are used to describe family and social measures, reflecting the diverse interests of researchers who have investigated them. Some have focused on bidirectional relationships between work and the family environment, investigating variables such as work-family conflict or work-family balance. Others have examined relationships between working time and the broader social domain, which includes the family but extends beyond it. They have investigated variables such as work-life conflict or work-life balance. In other cases, research has been focused on unidirectional relationships, that is, the occurrence of conflict in one particular direction, such as work interfering with family or the home situation (work-tofamily conflict), or the family/home situation interfering with work (family-to-work conflict). In this paper, an effort has been made to avoid using terms that are synonymous but, as several of the terms refer to genuinely different phenomena, the results of individual studies are discussed in terms of the specific variables that they investigated.

Despite attempts to promote the belief that 'the 24/7 society' is a normative concept, a stable social rhythm of evening and weekend activities is identifiable, at least in western industrialized societies. These hours of the day and the week are still considered the most valuable times for social and family interactions ${ }^{8-10)}$. In the same way as shift work encroaches on valuable 'sleep time', shift work and work on evenings and weekends can also encroach on valuable 'social time' and produce 'social desynchronization' by reducing the time available for social interaction, leisure and family activities.

This desynchronization of personal and social-behavioral structures may increase impairments to social life ${ }^{11)}$, which has been well documented in the literature on night and shift work (e.g. Arendt ${ }^{12)}$, Colquhoun et al. ${ }^{13)}$, Tucker and Folkard ${ }^{14)}$; see also ${ }^{2)}$ ). Thus, non-standard working hours such as shift work and work on evenings and weekends directly affect balance between the work and nonwork domains and social participation (e.g. Bittman ${ }^{15}$, Brown et al. ${ }^{16)}$, Lyonette and Clark ${ }^{17)}$, Tucker et al. ${ }^{18)}$, Tucker et al. ${ }^{19)}$, Wirtz et al. ${ }^{20)}$ ).

A wide range of factors from various domains, including demographics, health, paid work and home (e.g., family, private life) domain, have been linked with work-family conflict ${ }^{21-23)}$ ). Since the amount of time demanded by work and the timing of work within the day and week are among the most obvious ways in which work may affect private life, working time arrangements are one important determinant of the work-family balance ${ }^{24)}$. Several distinctions can be made regarding working time arrangements, for example between work schedules (e.g. various forms of (irregular) shift work versus day work) and the number of working hours (e.g. per day or week). Moreover, they 
should ideally be interpreted in the context in which they take place, e.g. in secure employment versus uncertain or unpredictable circumstances, like precarious work. Workfamily conflict among shift workers is thought to arise predominantly because shift work involves working and living patterns that diverge from community rhythms of social, recreational and domestic activity ${ }^{25}{ }^{26}$. For day workers, subgroups of working hours (e.g. full-time versus part-time work) may be associated with different risks of work-life conflict. Because hours of work interrelate with shift work types, the number of working hours should also be taken into account when studying the impact of work schedules, and vice versa. Further, working time arrangements mainly concern the structure of work. Apart from structural components, content components of work, such as job demands or skill discretion, are also critical to understanding the impact of work on employees and their families ${ }^{27)}$ and should therefore be controlled in research on the effects of working time arrangements on workfamily conflict. The same is true for characteristics of private life (e.g. having dependent children, responsibility for housekeeping), personal characteristics (e.g. personality, chronotype), and health status (e.g. having a chronic illness) for example ${ }^{28)}$.

\section{Effects of Different Working Time Arrangements on Workers, Family and Community}

\section{Long working hours and compressed work weeks}

Long daily and/or weekly working hours, whether combined with shift work or not, have been shown to negatively affect occupational safety and health ${ }^{13}{ }^{29}$. Evidence on the social and family effects of working overtime (e.g. more than contractually agreed hours) is inconclusive, due to definitional inconsistencies and methodological limitations ${ }^{30)}$. Some cross-sectional studies (e.g. Peters et $a l^{31)}$ ) and longitudinal studies (e.g. Jansen et al. ${ }^{28)}$, Jansen et al. $^{32)}$ ) find an association between overtime and higher work-family conflict while others find a positive association with higher satisfaction ${ }^{33)}$. However, employees often prefer long daily hours that result in fewer working days per week ${ }^{34,35)}$. These so-called "compressed work weeks" aggregate a fixed number of weekly work hours into fewer, longer shifts or work days. For example, a 40-h work week may consist of four shifts of ten hours instead of five shifts of eight hours. A review by Bambra et al. ${ }^{36)}$ showed consistent improvements in subjective work-life balance when compressed work weeks were introduced.
But this may lead to a tradeoff; for example, 12-h-shifts allow more consecutive time for domestic duties, family and social life, but these very long shifts are likely to pose a high strain on workers, leading to longer recuperation times that may effectively shorten the available free time, between shifts and on work-free days, for leisure activities or family responsibilities ${ }^{34)}$. In cases of sufficient remuneration, however, a hypothetical work hour reduction to four instead of five days per week (e.g., $32 \mathrm{~h}$ work per week instead of 38 or $40 \mathrm{~h}$ ) could be beneficial without the trade-off of long work days.

\section{Shift schedule characteristics}

Specific characteristics of the shift schedule may affect social and family life, depending on the degree of social desynchronization they produce ${ }^{37}$.

Shift schedules with a slow rotation (e.g., five to seven subsequent shifts of the same type followed by two to four leisure days) produce a large number of consecutive days that are not available for social interaction, especially during periods of afternoon or night shifts. Conversely, schedules with fast rotation (i.e., maximum of two to three subsequent shifts of the same type; e.g., two morning, two afternoon and two night shifts followed by three days off) allow frequent (even if short) resynchronization with the social rhythm, which reduces impairments to family and social life ${ }^{38-40}$. Accordingly, these schedules have been related to an increase of subjective work-life balance ${ }^{41-44)}$. In some studies (e.g. Tucker ${ }^{35)}$ ), however, a simultaneous change in the shift system and reduction of work hours makes it difficult to say which intervention had caused the positive effects on work-life balance.

Schedules with forward rotation (i.e., rotating from morning to afternoon to night shift) are often reported to be more favorable than those with backward rotation (i.e., rotating from night to afternoon to morning shift), not only with regard to biological rhythms but also for social well-being ${ }^{45,46)}$. However, a review by Bambra et al. ${ }^{47)}$ found no evidence in favor of either forward or backward rotation when work-life balance was investigated in two intervention studies.

Additionally, evening and weekend work-separately and in combination - directly interfere with socially valuable time and thus increase the risk of impairments to work-life balance, health, and occupational safety, even when separated from the effects of shift work ${ }^{48)}$. 


\section{"Flexible" and precarious work, and irregular working hours}

Debates about contemporary workplace challenges, such as enhancing the workforce participation of women and older workers, frequently emphasize the benefits of 'flexible work ${ }^{49)}$. Research on flexibility most often focuses on organizational policies and practices intended to give workers greater control over how, when or where they work $^{50-52)}$. However, the insecure and contingent forms of work organization collectively known as 'precarious work' are also widely described as 'flexible'. Significantly, though, precarious work is primarily intended to achieve benefits for employers, such as labor intensification or a transfer of financial risks to workers ${ }^{53-55)}$. It is therefore important to distinguish between employer- and workeroriented forms of flexibility ${ }^{49,53,56)}$.

Definitions of precariousness usually refer to work contracts that are insecure, with no presumption of longterm tenure ${ }^{57)}$, or 'contingent' often with variable hours that can be changed at short notice ${ }^{58)}$. Common forms include casual, temporary, agency or sub-contract work ${ }^{59}$, ${ }^{60)}$. However, organizational practices can influence how much precariousness workers experience ${ }^{61)}$ and consequently the nature of the employment contract is only a partial measure ${ }^{62,63)}$. For example, workers in nominally secure, ongoing jobs may report precariousness as a result of organizational changes such as downsizing and outsourcing ${ }^{63-66)}$, which may be reflected in perceived job insecurity, vulnerability, and powerlessness ${ }^{56,61,67)}$

Precarious work has contributed to the expansion of irregular working hours through arrangements such as oncall or casual work and 'zero hour' contracts, that do not have set daily or weekly working hours and often result in unpredictable work schedules ${ }^{49,68,69)}$. Employers and politicians often argue that these variable hours are flexible for the worker, and hence family-friendly, but research generally does not support this assertion (e.g. $\operatorname{Hayman}^{70)}$ ). Irregular or unpredictable working hours are usually associated with greater work-life conflict ${ }^{53,68,69)}$ and poorer health, in terms of cardiovascular disease, fatigue and various aspects of mental health for example ${ }^{53,56,59,69,}$ $71,72)$. Work-life conflict may also moderate or mediate the negative effects of variable hours and shift work on health ${ }^{73-77)}$. On the other hand, regular working times provide predictability and facilitate planning of social and family activities ${ }^{49}$.

\section{Hours control, flexibility and variability}

If workers have relatively high control over their work schedules, even highly variable hours may not be associated with greater work-life conflict or poorer health, and may actually enhance participation in family and social activities $^{49,51,59,69,70,74,75)}$. Costa et al. ${ }^{53)}$ distinguished between two forms of irregular working hours: 'variability', when hours are largely controlled by employers, and 'flexibility', when hours are subject to greater individual worker control. Using European data collected in 15 countries, they derived simple categorical measures of variability ('variable, partially variable, fixed') and flexibility ('flexible, partially flexible, rigid'). Both variables were significantly related to almost all of the 23 health and wellbeing variables measured. Flexibility was associated with less work-life conflict ('unfavorable adjustment to family and social commitments') while variability was associated with greater conflict. When various demographic and work-related control variables were included in the analysis, flexibility had the second-strongest relationship with work-life conflict (with an odds ratio of 2.41 vs. 2.47 for night work).

Australian research on casual $^{1}$ and ongoing workers in call centers supported these findings using different measures of variability and flexibility ${ }^{69)}$. Two-week retrospective logs of working times were used to calculate the mean absolute deviations of starting times, finishing times and daily shift length (the irregularity of hours). Schedule control was measured using three self-report items (e.g. 'I have sufficient control over the shifts that I work'). The results indicated greater irregularity was associated with greater dissatisfaction with working hours and, in turn, greater work-life conflict and poorer mental health. However, an interaction between schedule control and variability indicated that increasing schedule control was associated with a diminishing relationship between hours variability and hours dissatisfaction (and hence work-life conflict and mental health). In other words, even when hours were highly irregular, high control (worker-oriented 'flexibility', as defined by Costa et al. ${ }^{53)}$ was associated with better health and well-being. Conversely, when control was low and irregularity high (employer-oriented 'variability') poorer health and wellbeing were reported. This study therefore supported the prediction of Costa et $a l .{ }^{53)}$ that the negative effects of hours variability diminish as worker control over the work schedule increases.

\footnotetext{
${ }^{1}$ Casual employment in Australia is defined as work in which the employee does not have various rights and benefits, including notice of dismissal, redundancy or severance payments, paid annual leave or sick leave, and paid public holidays ${ }^{78)}$.
} 
A systematic review ${ }^{79)}$ of studies examining relationships between worker control over working time and worklife balance also found a moderately strong association in cross-sectional studies and also moderately strong evidence of a causal relationship in the three intervention studies identified.

Interestingly, although most research indicates that worker-oriented flexibility reduces work-life conflict, some studies show partial positive effects or none at all. For example, even high autonomy did not completely balance out the impairing effects of non-standard working times in several studies ${ }^{5,20,56)}$. This may be because flexibility is usually constrained within limits set by employers and even largely self-determined working hours may interfere with social rhythms if they are very long or concentrated in the evenings or on weekends. The 'perceived usability' of the flexible work arrangement $\left(\operatorname{Hayman}^{70)}\right.$, p. 328) may also help to explain this inconsistency. It is defined as the extent to which workers feel they can take advantage of flexible work arrangements formally available to them. Hayman's findings confirmed that workers who perceived flexible hours to be 'usable' reported less work-life conflict and greater 'work-personal life enhancement'. Perceived usability may therefore represent a critical element of worker control over working hours, without which workers are less likely to use the flexibility apparently available to them.

On the other hand, actual working hours resulting from increased work hour autonomy are rarely examined. An intervention study by Garde et $a l^{80)}$, in which work hour autonomy was increased, showed improvements in health and recovery outcomes. However, no actual changes in work hours were observed in the intervention group with increased autonomy. Thus, changes in work hours did not explain the observed overall benefits for health and recovery. A possible reason might be insufficient measurement of the various ways in which collective and individual working hours can change. Another hypothesis is that cognitive processes influence the reporting of health outcomes in studies of self-controlled work hours. Thus, selfdetermined work hours are seen as more favorable, even when the actual work hours have not changed ${ }^{37)}$.

\section{On-call work}

On-call (or stand-by) work is a form of work scheduling characterized by unpredictable and irregular working hours over which workers have little control. Its requirements vary between industries, but on-call workers are generally expected to be available to work at short notice, irrespective of whether they are asleep, at work, or engaged in family or social activities ${ }^{81)}$. Despite wide-spread use as a cost-effective form of variable work, there is relatively little systematic evidence demonstrating the impact of being 'on-call' ${ }^{81,82)}$.

An overview of the available literature shows that most studies have been qualitative and interview-based ${ }^{83-87)}$ or self-report (questionnaire data) ${ }^{88-93)}$ and conducted in the healthcare sector ${ }^{85,86,88,89,91,93-95)}$, particularly among General Practitioners (GPs). They have focused on outcomes for on-call workers, such as workload ${ }^{86,91,92)}$ and sleep $^{88,91,92,94-98)}$. Thus, findings discussed in this section cannot necessarily be generalized to other sectors or the general population, since GPs have a high socio-economic status and specific working conditions.

Direct evidence demonstrating the impact on the family, social and community networks of the people who do oncall work is also lacking. There are only a few publications that assess the impact of on-call work on family members rather than the workers themselves ${ }^{84,85,98-100)}$ and these qualitative studies unanimously show negative effects. Spouses of GPs in the United Kingdom reported frustration at the constant interruption to family life ${ }^{85)}$. Similarly, spouses of Australian emergency services volunteers cited the unpredictability of call-outs when asked to identify difficulties associated with managing competing demands of emergency service work and family ${ }^{100)}$. In a study of doctors, on-call work was also shown to impact their ability to spend quality time with their children ${ }^{84)}$.

There is a larger body of indirect evidence, which focuses on on-call workers and their perceptions of the family, social, and community impact. Again, almost without exception, studies highlight conflict between the competing demands of family and on-call activities ${ }^{79-85,87,90,93,101)}$. The main sources of conflict relate to regular interruptions to family life ${ }^{85,87,93,100)}$, restrictions of life's activities outside work $^{83,84,90,100)}$ and generally doing less household and social activities during call periods ${ }^{90)}$. Interestingly, on-call workers are often acutely aware of the impact on their partners with several studies specifically noting the support role that spouses and families play and sacrifices that they make for the on-call work to occur ${ }^{83,84,87,97)}$. Sleep disturbance or sleep loss is a well-documented consequence of on-call work ${ }^{89,91-96,101-103)}$ and thus family may also suffer negative consequences as a result, particularly given the known impact of sleep loss on mood (e.g. Lockley et al. ${ }^{104)}$ ). However, detailing the ramifications of on-call workers' sleep disturbance for their families was not within the scope of these studies. 
Negative impacts of on-call work on the community are also rarely examined in the research. However, similar to family and social impacts, the impact of on-call work on the community could be an indirect result of sleep disturbance/loss among on-call workers. In reference to overnight on-call work, one GP reported "... I think that affects the quality of care you can give if you are chronically tired ..."86). Impacts for the community may also relate to an inability to retain workers in their roles. For example, in a study of physicians, on-call was associated with low job satisfaction and low workability, with job satisfaction in particular linked to retention issues which may also have consequences for the community ${ }^{101)}$.

Communities reap benefits from on-call work patterns, such as the round-the-clock availability of essential health and emergency services. In Australia for example, volunteers, who are on-call $24 \mathrm{~h}$ a day, $365 \mathrm{~d}$ a year, constitute a large proportion of the emergency services workforce and communities rely on these volunteers being available at any given time for rescue and response in emergency management. Worryingly, the size of the volunteer workforce is currently on the decline ${ }^{105)}$. While the reasons for declining volunteer numbers are varied, work-family conflict is often reported and, further to this, the on-call component / unpredictability of emergency services work have been implicated in this work-family conflict ${ }^{98,106)}$. A diminishing volunteer workforce has direct and serious ramifications for disaster response and community resilience.

While the inherent nature of on-call is that it is unpredictable, there may be ways to minimize the negative impacts of on-call and other types of unpredictable work. Practical examples could include removing an element of unpredictability in the lead up to an on-call shift/period by pre-empting a work shift (based on weather predictions) the day prior. In doing so, workers would know they will be going into work the next day and in a recent publication ${ }^{107)}$, this scenario was deemed as being more favorable by on-call emergency services workers than the uncertainty of not knowing if or when they would be needed and modifying their lives accordingly. Finally, targeted research, focused on better understanding of the impact of 'on-call' - particularly that period of unpredictability between calls - would also inform the management of oncall periods into the future.

\section{Remote or offshore work}

In some occupations, workers are required to work at remote places, for example offshore oil platforms, or mining. Usually, these are "fly in - fly out" (or "drive in - drive out") occupations where workers spend a long consecutive time at the work site and return home for a long stretch of free-time (e.g., 2-3 wk of 12-h-shifts followed by $2-3$ wk off in the offshore petroleum industry in the EU). These cycles can lead to very specific workhome-arrangements, especially for workers with families. However, there is little empirical evidence regarding the work-family-interface of these remote shift workers. In some studies, remote or offshore workers reported difficulties for the family, such as repeated partings and reunions, the impact of intermittent father absences on children and problems communicating with the absent partner ${ }^{108-110)}$. Other studies did not find increased social or family difficulties ${ }^{111,112)}$ but in the case of one study ${ }^{111)}$ this might have been due to a very long onshore period (4 wk) in between offshore work. It should also be kept in mind that the population of offshore or remote workers are a highly selective group and survivor bias may play a role, in that mainly workers without major difficulties stay in these work environments.

Reciprocal relations between working time arrangements and work-family conflict

To date, many studies have explored associations between characteristics of working time arrangements and work-family conflict, summarized in different reviews (e.g. Byron $^{21)}$, Michel et al. ${ }^{23)}$, Nijp et al. ${ }^{79)}$ ). However, the vast majority of primary studies included in these reviews were cross-sectional in nature, precluding the possibility to make causal assertions regarding the nature of the relationships observed (e.g. Allen et al. ${ }^{113)}$, Casper et al. ${ }^{114)}$ ). Additionally, the few longitudinal studies so far have mainly focused on the first proposed causal relationship, that is, the impact of working time arrangements on the development of work-family conflict over time (e.g. Jansen et $_{\text {al }}{ }^{28)}$, Jansen et $a l .{ }^{32)}$, Grice et al. ${ }^{115)}$ ). However, the possibility of a reversed relation has been generally overlooked: employees struggling to combine work and family life may seek ways to adapt their current job to better reconcile the two, for example by changing their working time arrangements ${ }^{116)}$. To our knowledge, the few prospective studies available to date, provide clear indications of such a reciprocal relationship. Studies among a Dutch working sample, for example, show that workfamily conflict in male three-shift workers was associated with a significantly increased risk of leaving the shift work job over time ${ }^{32,116)}$. For day workers, the effects of workfamily conflict on a reduction of working hours were 
substantial and significant among women when a one-year follow-up was considered, while effects decreased after two years of follow-up, but nonetheless remained significant. Among male full-time workers, work-family conflict was not significantly associated with reducing working hours over one year of follow-up, but significant effects did appear when at the two-year follow-up. These findings indicate a gender effect, in that generally women may appear to adjust their working hours faster as a consequence of work-family conflict, compared to men ${ }^{116)}$. Clearly, these findings should be interpreted in their context. For example, among couples, choices on changing work hours usually are not taken by individuals in isolation but rather in the context of households as a whole ${ }^{117)}$, and therefore depend on the division of roles, e.g. the breadwinner role, among the members of the household.

\section{Effects of Parents' Shift Work and Non- standard Working Hours on Children and Families}

While the previous sections deal with effects on the workers themselves, this chapter is aimed at describing effects of shift work and non-standard working hours on their families and children. In this way, the chapter specifically addresses aspects of working schedules that can directly affect people who live with shift workers and with those who work non-standard hours. These effects derive from the need to counteract socially established habits throughout the civilization process, related to the synchrony between individuals ${ }^{118}$ ). In fact, working on shifts requires workers to live out of social synchrony, thus challenging a convention central to humans: the sociotemporal order of life, including family life ${ }^{119)}$. The chapter encompasses situations in which working hours tend to prevent or impair family life with effects on mothering, fathering as well as partner roles. Literature data focuses (i) on emotional problems and risky behaviors among both shift workers' children and adolescents and (ii) on relationship with partners, with information on divorce/separation and marriage quality among male and female shift workers. The research literature points to a general statement on detrimental effects of shift work to children and family, although there is evidence of positive work-family experiences derived from workers and their families' strategies to deal with demands of working hours.

Most studies on shift workers' children describe poorer emotional and development outcomes, compared to children whose parents work in standard work schedules, as reviewed by Li et $a l^{120)}$. Several aspects of the family environment act as mediators, such as depressive symptoms of parents, poor quality of parenting, reduced parentchild interaction, and less supportive home environment. The exposure to parents' shift work in the early years of childhood is particularly harmful ${ }^{120-122)}$. Larger effects are described among families in low socioeconomic levels ${ }^{121-123)}$, and single parent families ${ }^{124)}$. Investigations on adolescents are scarcer when compared to those that focus on children. A large representative sample of young men and women in the United States was analyzed with regard to adolescents' (13-14 yrs old) risky behaviors such as substance use (cigarette smoking; alcohol use; drug use), delinquency, and sexual behavior ${ }^{123}$. Night work (but not evening work) among mothers was significantly related to less time with children, and lower quality home environments, which were linked to risky behaviors. The effects of night shifts among mothers were stronger if children were in pre-school or middle childhood years $\left.{ }^{123}, 125\right)$, thus confirming above-mentioned data directly observed among young children ${ }^{120}$.

In a longitudinal approach for analyzing marital stability among shift workers, Presser ${ }^{126)}$ observed that chances for divorce or separation were influenced by the presence of children, the type of non-standard schedule, the workers' gender, and the duration of marriage. Night work combined with parenting seemed to be the most detrimental situation for both the male and female sample. Among men with children, married less than 5 yrs (at wave 1), working fixed night shifts increased the odds of divorce/ separation by six times, compared to day workers. Among women with children married for more than 5 yrs (at wave 1) fixed night work made separation/divorce three times more likely, compared to day workers. Similarly, in a nationally representative sample of the USA population, night work was associated with greater marital instability, compared to weekend or daytime work ${ }^{127)}$.

Although the overall picture points to detrimental effects of non-standard working hours on marriage quality and children wellbeing, no generalizations can be made, since the consequences are largely dependent on the specific schedule and the family characteristics ${ }^{128)}$. For instance, in a study on dual-earner families with children (8-14 yrs old), Barnett \& Gareis ${ }^{129)}$ described a "regendering" of household and childcare duties in families in which the mothers worked evening-shift work (3:00pm-11:00pm). In that case, fathers dedicated more time to their children than fathers whose wives worked in daytime shift, which is a benefit in relation to marriage stability ${ }^{130}$. 
Another aspect of parental involvement with children (up to 12 yrs of age) was observed by Pagnan et al. ${ }^{131)}$ through individual semi-structured face-to-face interviews, coupled with questionnaires. When investigating the decisionmaking of couples (interviewed separately) regarding work at non-overlapping schedules, the authors noted that knowing that the child is cared for by a parent is seen by workers as a factor that compensates for costs reported, such as tiredness, for example. Quantitative and qualitative data were also employed by Haddock et al. ${ }^{132)}$ in a study with dual earner couples who self-evaluated as successful in the domains of family and work. In these workers' view, the flexibilization of schedules controlled by the worker was the practice that most stood out as beneficial to the work-family interface. For example, many workers reported doing professional tasks early in the morning or at night, at work or at home, so as not to sacrifice time for the family. Working on non-traditional schedules, such as compressed work weeks, in the evening or on night shifts, allowing at least one partner to be at home during the day, also proved to be beneficial to the family. Taken together, the studies by Pagnan et al. and Haddock et al. ${ }^{131,132)}$ show how the so-called triangulation of quantitative and qualitative approaches, rarely used in shift work research, can contribute to the understanding of subtle aspects of the complex work-family interface.

Besides highlighting the relevance of partner support to marriage quality, and other beneficial effects of shift work, these results also direct attention to a crucial variable to be considered in the context of work-family studies: the opportunity to choose a work schedule ${ }^{129}$. For example, less negative effects of night shifts on partnership quality within a representative Dutch sample than within United States ones may be attributable to advantages in Dutch legislation concerning employment protection and wage agreements. In their interviews, Mills and Täht ${ }^{133)}$ observed that, under certain circumstances, workers who did not like night or rotating shifts actively left those shifts (and had the protection and option to do so), leaving a residual group that was more satisfied with work schedules than workers from the United States. In a comprehensive review of studies examining outcomes for the children of parents on nonstandard work schedules, Li et al. ${ }^{120)}$ noted that the two studies that reported reduced risky behavior among adolescents of workers in nonstandard schedules refer to parents who tended to choose their schedules or have some control on work time ${ }^{123,124)}$. In addition, parents working nonstandard schedules were more likely to have higher family income, so that the authors associated situations in which parents work "flexible work schedules of their own choosing" with reduced incidence of risky behaviors in their adolescent children. In that case, improvement of parental knowledge of childrens whereabouts possibly contributed to reduce their health and wellbeing risks $^{123)}$.

\section{Work-family Interface and Dispositional Variables among Shift Workers}

There is a scarcity of research concerning the relationship between dispositional variables (i.e., personal characteristics such as personal inner determinants of reactions) and the work-family interface among shift workers. However, research on large populations (e.g. representative national samples) not focusing on but also including shift workers may help to increase understanding of this relationship.

Early studies focused mainly on one direction of workfamily conflict and on a narrow range of dispositional variables. A significant proportion of variance in work-family conflict was explained by negative affectivity ${ }^{134,135)}$. Both directions of work-family facilitation, a slightly different concept of positive work-family interaction, were related to positive affect and core self-evaluations ${ }^{136}$. Type A personality (i.e., individuals who can be characterized as more competitive, highly organized, ambitious etc.) was related to work-family facilitation ${ }^{134)}$ and specifically to impatience-irritability component of Type A behavior (but not achievement striving component ${ }^{137)}$.

In the first decade of the 21 st century, studies included the positive side of the work-family relation as well, and concentrated mainly on relationships with the five-factor model of personality (also known as "Big Five") ${ }^{138)}$. Work-family conflict in both directions was positively related to neuroticism ${ }^{136,137,139-141)}$ and negatively to extraversion $^{140)}$, conscientiousness ${ }^{137,139-141)}$, and agreeableness ${ }^{137,139-142)}$. Openness to experience was not related to work-family conflict in a majority of studies, but, in one study, it was found to be positively related to work-family conflict in men ${ }^{143)}$. Work-family facilitation was related to openness to experience ${ }^{140,141)}$ and both directions of work-family facilitation were related to extraversion, conscientiousness, and agreeableness ${ }^{139,} 140$ ).

Studies over the past decade added a broader range of dispositional variables. Emotional intelligence (selfcontrol) was negatively related to work-family conflict in both directions ${ }^{144)}$. Cohen ${ }^{145)}$ examined the relationship between individual values and work-family interface and 
found that power (understood as control or dominance over people and resources) was positively related to work-family conflict of both directions. A strong job performance-based self-esteem was found to be a risk factor for work-home conflict ${ }^{146)}$. Internal locus of control was negatively related to work-family conflict in both directions and positively related to work-family facilitation ${ }^{147)}$.

Work-family interface among shift workers was assumed to be an aspect or correlate of shift work tolerance ${ }^{148,149)}$ and therefore predicted by the same dispositional variables. Individual differences variables associated with circadian rhythm parameters, including morningness ${ }^{150)}$, ability to overcome drowsiness and flexibility of sleeping habits ${ }^{151,152)}$, have been studied in this context. A negative relationship between morningness and workfamily conflict was found in one study ${ }^{153)}$. Another found that individual differences in circadian rhythm parameters predicted work-family interface ${ }^{154)}$ : Languidity (the inability to overcome drowsiness) and to a smaller degree morningness predicted work-family conflict in both directions. Flexibility in sleeping habits explained a limited amount of variance in work-family facilitation but was not related to work-family conflict. The results suggest, that (i) shift workers who are better at overcoming drowsiness and who are classified as 'morning individuals' experience lower work-family conflict and (ii) shift workers who are more flexible in sleeping habits experience higher workfamily facilitation.

\section{Summary and Research Recommendations}

The studies described in this paper show that working time arrangements may have both beneficial and adverse effects on the level of conflict between work and different social and family outcomes under specific conditions. Generally, working time demands, such as the specific shift work types mentioned above and long work hours, were associated with higher conflict, whereas characteristics reflecting worktime control, regularity and predictability were associated with less conflict between work and social or family life.

The studies further demonstrate that the impact of different aspects of working time arrangements should be interpreted in the particular context in which they took place, for example in secure employment versus uncertain or unpredictable working arrangements, such as precarious work. Also, the perceived usability of flexible hours, or the ability to choose a particular work schedule, appears to play a vital role.
It should be noted that many of the studies conducted so far relied on cross-sectional designs, precluding causal attributions regarding the nature of the relationships observed (e.g. ${ }^{113,114)}$ ). However, the limited number of prospective studies available to date show that various aspects of working time arrangements play a significant role in the development of conflict between work and social or family life over time. Moreover, relevant reciprocal relations are demonstrated, indicating that important secondary selection processes may take place, in terms of reductions in working hours, and transitions in work schedules as a consequence of conflict between work and social or family life. Consequently, it might even be possible that the negative effects of non-standard working hours have therefore been underestimated.

More prospective and intervention studies, conducted in different contexts and among different subgroups, are required to increase understanding of the impact of working time arrangements on workers, family and community. Also, the consistency of reciprocal relations should be explored in future studies, to find out whether such associations exist across different populations or contexts. It would also be valuable to examine changes in exposure before changes in outcomes; for example, by investigating change in work-family or work-life conflict before the change in working time arrangements. This is particularly relevant in studies in which employees have already been in the labor market for some years, and are therefore in the middle of an ongoing process both with regard to choices in working time arrangements and combining work and private life. Longitudinal observational studies, investigating both changes in exposure before changes in outcome and the dynamic relationships between these variables over time, as well as (natural) experiments, will reveal more clearly the details of causal mechanisms and confounding or mediating factors. This evidence should be gathered before preventive measures or (targeted) interventions, including aspects of working time arrangements, to reduce work-family or work-life conflict are developed and implemented, because effective interventions require a full understanding of the multifactorial etiology of workfamily conflict and its consequences ${ }^{155)}$.

Despite the evidence regarding the difficulties faced by both shift workers and their families, researchers should recognize that workers and their families are able to develop strategies to deal with challenges under favorable circumstances. That is why the research agenda in this area should consider both negative and positive family experiences (e.g., more time for some shift working parents with 
their children in comparison to day work, see also section D) associated with working hours ${ }^{156,157)}$. The effects on the community have rarely been investigated, and additional research, for example on elderly care and voluntary work, is needed to fill this gap. A more comprehensive understanding of this subject also demands attention to methodological issues, such as the clear characterization of shift (work schedule, weekly work hours, and weekend work) and sample characteristics ${ }^{156}$, negotiability and predictability of work hours ${ }^{157)}$, and availability of childcare facilities ${ }^{121)}$, among other demands on family life.

A limitation of this review is the focus of most studies on a relatively homogenous work force, mostly from western societies, and very little research from developing countries or non-traditional families and other cultures. Different rosters will most likely affect different cultures and demographics in different ways. The scope of future research should be expanded to facilitate comparisons of the effects of specific working hour arrangements between different cultures, demographic cohorts, and working populations.

Lastly, there is a clear research gap regarding the role of dispositional variables in work-family interface among shift workers. Such research may help to identify biological factors and behavioral patterns that prevent negative and facilitate positive relations between work and family. Practical application of such findings may serve under some circumstances for personnel selection/counselling to shift work or for training purposes for those who already work shifts.

\section{Clinical Recommendations and Intervention Strategies}

From a preventive point of view, work scheduling should be targeted as an intervention strategy on the workplace or group level to minimize social impairments. According to the research findings described above, the following recommendations for working time arrangements can be derived:

- Work schedules should minimize long hours, work on evenings and weekends, and irregularity (e.g., work scheduling should aim at regular, predictable work hours, without or with only a minimum amount of stand-by or on-call work).

- Including at least some control over work hours is very likely to increase work-life balance and allows workers to adapt their working time arrangements to their personal needs.
- If shift work is involved, fast rotating shifts that allow for at least some work-free evenings each week appear to be the preferable option.

The development and use of sophisticated software applications will help to facilitate ergonomic work scheduling and worker-oriented flexibility by integrating both health and social aspects of work scheduling. Of course, if health and social aspects are not integrated into these software applications, a pure optimization of organizations' staffing requirements may lead to irregular or unpredictable working hours or increased work load, and therefore the applications should be equipped with tools for health and social assessment of working hours.

In addition to actions aimed at adjusting working hours, recommendations include specific measures related to the children of employees working in shifts and non-standard working hours. In a critical review of the literature on well-being among shift workers' children, Li et al. ${ }^{120)}$ emphasize several actions that can be implemented by society as a whole and government to reduce deleterious consequences of non-standard working hours on children and families. Securing adequate remuneration for shift work schedules especially in low-income sectors can be an effective intervention since children in low-income families are more vulnerable. Financial support can help workers as regards facilities related to child care, and beforeand after-school care for school-age children, for instance. These factors can contribute to reducing the negative association between shift work and non-standard working hours and child development. But, similar to other problems associated with non-standard work hours, extra pay is not a solution for all the difficulties faced by shift workers' families. If the absence of childcare facilities is a problem for shift workers in some countries, in others, the concept of affordable daycare does not solve issues related to feelings of guilt for not spending sufficient time with children $^{158)}$. In the context of these issues, tag-team parenting, where parents alternate their schedules in such a way that each parent can stay at home and care for the children, can be a strategy to address the costs of childcare ${ }^{159)}$, but may on the other hand reduce time for the couple to spend with each other. Besides necessity, this practice may also be related to the value posed by some families to parental care as opposed to other types of childcare arrangements ${ }^{157)}$.

Aspects related to neighborhood and community resources should also be considered; for example, sufficient child care during working hours, the provision of school, before- and after-school care, all of which can benefit children's development and reduce stress among parents 
who work shifts. Depending on the household context, child care might be needed especially at certain times of the day (e.g., shift working parent needs to sleep) or even during the night (e.g., single parent working night shifts). Without these community resources, shift workers may resort to less reliable solutions for child care, or may even be unable to carry out their jobs.

On an individual level, training and education for workers and their families can be beneficial. One example is the Australian support website "Mining Family Matters"160) where employers as well as workers from mining and remote operations ("Fly in-fly out") and their families can find information, community groups, and resources to balance work and family life. These include forums and columns written by experts, e.g. psychologists giving recommendations for maintaining relationships with a remote-working spouse, advice on healthy lifestyle, tips for helping children cope with an absent parent, information about mining towns, and much more.

Additionally, providing workers who are able to control their working hours with information on healthy and social work scheduling would help them to minimize (unintentional) social impairments due to their work hour choices. However, few scientific studies have investigated such individual interventions, and therefore these recommendations are not based on strong evidence.

Overall the picture of workers and their social and family life is so diverse that a "one size fits all" preventive strategy is bound to fail. Different countries and different parties (e.g., unions, employer representatives) might have a very different focus. Context specific interventions and preventive measures should therefore be chosen and combined carefully to help improving work-life balance amongst shift workers of different socio-cultural backgrounds, occupations, and countries.

\section{References}

1) Wong IS, Dawson D, Van Dongen HPA (2019) International consensus statements on non-standard working time arrangements and occupational health and safety. Ind Health 57, 135-8.

2) Costa $G$ (2016) Introduction to the problems of shift work. In: Iskra-Golec I, Barnes-Farell J, Bohle P (Eds.)., Social and family issues in shift work and non standard working hours, 19-35, Springer, Basel.

3) Eurostat (2017) Population in employment working on Sundays. http://ec.europa.eu/eurostat/web/gdp-andbeyond/quality-of-life/population-in-employment-workingsundays. Accessed January 9, 2017.
4) Eurostat (2017) Population in employment working on Saturdays. http://ec.europa.eu/eurostat/web/gdp-andbeyond/quality-of-life/population-in-employment-workingsaturdays. Accessed January 9, 2017.

5) Eurostat (2017) Population in employment working on Evenings. http://ec.europa.eu/eurostat/web/gdp-andbeyond/quality-of-life/population-in-employment-workingevenings. Accessed January 9, 2017.

6) Arlinghaus A, Nachreiner F (2014) Health effects of supplemental work from home in the European Union. Chronobiol Int 31, 1100-7. [Medline] [CrossRef]

7) Moreno CRC, Marqueze EC, Sargent C, Wright KP, Ferguson SA, Tucker P. Working Time Society consensus statements: Evidence-based effects of shift work on physical and mental health. Ind Health, 57, 139-57.

8) Hinnenberg S, Zegger C, Nachreiner F, Horn D (2009) The utility of time-revisited after 25 years. Shiftw Int Newsl 25,52 .

9) Hornberger S, Knauth P (1993) Interindividual differences in the subjective valuation of leisure time utility. Ergonomics 36, 255-64. [CrossRef]

10) Wedderburn A (1981) Is there a pattern in the value of time off work? In: Reinberg A, Vieux N, Andlauer P (Eds.), Night and shift work: biological and social aspects. Advances in the biosciences, 495-504, Pergamon Press, Oxford.

11) Wirtz A, Giebel O, Schomann C, Nachreiner F (2008) The interference of flexible working times with the utility of time: a predictor of social impairment? Chronobiol Int 25, 249-61. [Medline] [CrossRef]

12) Arendt J (2010) Shift work: coping with the biological clock. Occup Med (Lond) 60, 10-20. [CrossRef]

13) Colquhoun W, Costa G, Folkard S, Knauth P (1996) Shiftwork: problems and solutions. Peter Lang, Frankfurt.

14) Tucker P, Folkard S (2012) Working Time, Health, and Safety: a Research Synthesis Paper. International Labour Office, Geneva.

15) Bittman M (2005) Sunday working and family time. Labour Ind 16, 59-81. [CrossRef]

16) Brown K, Bradley L, Lingard H, Townsend K, Ling S (2010) Working time arrangements and recreation: making time for weekends when working long hours. http://www.thefreelibrary.com/Wor $\mathrm{king}+\mathrm{time}+$ arrangements + and + recreation $\% 3 \mathrm{~A}$ + making+time+for+weekends.-a0237838393 Accessed February 19, 2015.

17) Lyonette C, Clark M (2009) Unsocial hours: unsocial families? Working time and family wellbeing. Relationships Foundation, Cambridge.

18) Tucker P, Bejerot E, Kecklund G, Aronsson G, Åkerstedt T (2013) Doctors' work hours in Sweden: Their impact on sleep, health, work-family balance, patient care and thoughts about work. Stressforskningsinstitutet, Stockholm.

19) Tucker P, Brown M, Dahlgren A, Davies G, Ebden P, Folkard S, Hutchings H, Åkerstedt T (2010) The impact 
of junior doctors' worktime arrangements on their fatigue and well-being. Scand J Work Environ Health 36, 458-65. [Medline] [CrossRef]

20) Wirtz A, Nachreiner F, Rolfes K (2011) Working on Sundays-effects on safety, health, and work-life balance. Chronobiol Int 28, 361-70. [Medline] [CrossRef]

21) Byron K (2005) A meta-analytic review of work-family conflict and its antecedents. J Vocat Behav 67, 169-98. [CrossRef]

22) Eby LT, Casper LM, Lockwood A, Bordeaux C, Brinley A (2005) Work and family research in IO/OB: content analysis and review of the literature (1980-2002). J Vocat Behav 66, 124-97. [CrossRef]

23) Michel JS, Kotrba LM, Mitchelson JK, Clark MA, Baltes BB (2011) Antecedents of work-family conflict: a metaanalytic review. J Organ Behav 32, 689-725. [CrossRef]

24) Grzywacz J (2016) Shift work and its implications for everyday work and family life: A foundation and summary. In: Iskra-Golec I, Barnes-Farrell J, Bohle P, (Eds.), Social and family issues in shift work and non standard working hours, 3-17, Springer, Basel.

25) Loudoun RJ, Bohle PL (1997) Work/non-work conflict and health in shiftwork: relationships with family status and social support. Int J Occup Environ Health 3 Supplement 2, S71-7. [Medline]

26) Walker J (1995) Social problems of shiftwork. In: Folkard S, Monk TH (Eds.), Hours of work Temporal factors in workscheduling, 211-25, John Wiley \& Sons, New York.

27) Barnett RC (1998) Toward a review and reconceptualization of the work/family literature. Genet Soc Gen Psych. 124, $125-82$.

28) Jansen NW, Kant I, Nijhuis FJ, Swaen GM, Kristensen TS (2004) Impact of worktime arrangements on workhome interference among Dutch employees. Scand J Work Environ Health 30, 139-48. [Medline] [CrossRef]

29) Folkard S, Lombardi DA (2006) Modeling the impact of the components of long work hours on injuries and "accidents". Am J Ind Med 49, 953-63. [Medline] [CrossRef]

30) Albertsen K, Rafnsdóttir GL, Grimsmo A, Tómasson K, Kauppinen K (2008) Workhours and worklife balance. Scand J Work Environ Health Suppl. 2008(5), 14-21.

31) Peters P, den Dulk L, van der Lippe T (2009) The effects of time-spatial flexibility and new working conditions on employees' work-life balance. Community Work Fam 12, 279-97. [CrossRef]

32) Jansen NWH, Kant I, Kristensen TS, Nijhuis FJN (2003) Antecedents and consequences of work-family conflict: a prospective cohort study. J Occup Environ Med 45, 479-91. [Medline] [CrossRef]

33) Holly S, Mohnen A (2012) Impact of working hours on work-life balance. Berlin: SOEPpapers 465, DIW Berlin.

34) Knauth P (2007) Extended work periods. Ind Health 45, 125-36. [Medline] [CrossRef]

35) Tucker P (2006) Compressed working weeks. International Labour Office, Geneva.
36) Bambra C, Whitehead M, Sowden A, Akers J, Petticrew M (2008) "A hard day's night?" The effects of Compressed Working Week interventions on the health and work-life balance of shift workers: a systematic review. J Epidemiol Community Health 62, 764-77. [Medline] [CrossRef]

37) Arlinghaus A, Nachreiner F (2016) Unusual and unsocial? Effects of shift work and other unusual working times on social participation. In: Iskra-Golec I, Barnes-Farell J, Bohle P (Eds.), Social and family issues in shift work and non standard working hours, 39-57, Springer, Basel.

38) Bonitz D, Grzech-Sukalo H, Nachreiner F (1987) Differential psychosocial effects of different shift systems. In: Oginsky A, Pokorski J, Rutenfranz J (Eds.), Contemporary advances in shiftwork research. Theoretical and practical aspects in the late eighties, 181-9, (Proceedings of the 8th International Symposium on Night and Shiftwork, Krakow/Koninki) Medical Academy, Krakow.

39) Grzech-Sukalo H, Hedden I, Nachreiner F (1990) The relation of periodic components and psychosocial impairment for selected shift rotas. In: Costa G, Cesana G, Kogi K, Wedderburn A (Eds.), Shiftwork: health, sleep and performance, 191-196, Peter Lang, Frankfurt am Main.

40) Hedden I, Grzech-Sukalo H, Nachreiner F (1990) Classification of shift rotas on the basis of periodic components. In: Costa G, Cesana G, Kogi K, Wedderburn A (Eds.), Shiftwork: Health, Sleep and Performance, 197-202 (Proceedings of the 9th International Symposium on Night and Shiftwork, Verona), Lang, Frankfurt am Main.

41) Härmä M, Tarja H, Irja K, Mikael S, Jussi V, Anne B, Pertti M (2006) A controlled intervention study on the effects of a very rapidly forward rotating shift system on sleepwakefulness and well-being among young and elderly shift workers. Int J Psychophysiol 59, 70-9. [Medline] [CrossRef]

42) Hornberger S, Knauth P (1995) Effects of various types of change in shift schedules: a controlled longitudinal study. Work Stress 9, 124-33. [CrossRef]

43) Knauth P, Kieswetter E (1987) A change from a weekly to quicker shift rotations: a field study of discontinuous threeshift workers. Ergonomics 30, 1311-21. [CrossRef]

44) Smith PA, Wright BM, Mackey RW, Milsop HW, Yates SC (1998) Change from slowly rotating 8-hour shifts to rapidly rotating 8-hour and 12-hour shifts using participative shift roster design. Scand J Work Environ Health 24 Suppl 3, 55-61. [Medline]

45) van Amelsvoort LG, Jansen NW, Swaen GM, van den Brandt PA, Kant I (2004) Direction of shift rotation among three-shift workers in relation to psychological health and work-family conflict. Scand J Work Environ Health 30, 149-56. [Medline] [CrossRef]

46) Janssen D, Nachreiner F (2001) Differential psychosocial effects of different shift systems. - A comparison of the effects of shiftwork under different systems in the chemical industry. Shiftwork International Newsletter, 10.

47) Bambra CL, Whitehead MM, Sowden AJ, Akers J, 
Petticrew MP (2008) Shifting schedules: the health effects of reorganizing shift work. Am J Prev Med 34, 427-34. [Medline] [CrossRef]

48) Greubel J, Arlinghaus A, Nachreiner F, Lombardi DA (2016) Higher risks when working unusual times? A crossvalidation of the effects on safety, health, and work-life balance. Int Arch Occup Environ Health 89, 1205-14. [Medline] [CrossRef]

49) Berg P, Bosch G, Charest J (2014) Working-time configurations: a framework for analyzing diversity across cultures. Ind Labor Relat Rev 67, 805-37. [CrossRef]

50) Hill EJ, Hawkins AJ, Ferris M, Weitzman M (2001) Finding an extra day a week: the positive influence of perceived job flexibility on work and family life balance. Fam Relat 50, 49-58. [CrossRef]

51) Lambert AD, Marler JH, Gueutal HG (2008) Individual differences: factors affecting employee utilization of flexible work arrangements. J Vocat Behav 73, 107-17. [CrossRef]

52) Masuda AD, Poelsmans SAY, Allen TD, Spector PE, Laurent M, Lapierre LM, Cooper CL, Abarca N, Brough P, Ferreiro P, Fraile G, Lu L, Lu CQ, Siu OL, O’Driscoll MP, Simoni AS, Shima S, Moreno-Velazquez I (2012) Flexible work arrangements availability and their relationship with work-to-family conflict, job satisfaction, and turnover intentions: a comparison of three country clusters. Appl Psychol 61, 1-29. [CrossRef]

53) Costa G, Sartori S, Åkerstedt T (2006) Influence of flexibility and variability of working hours on health and well-being. Chronobiol Int 23, 1125-37. [Medline] [CrossRef]

54) Quinlan M, Mayhew C, Bohle P (2001) The global expansion of precarious employment, work disorganization, and consequences for occupational health: a review of recent research. Int J Health Serv 31, 335-414. [Medline] [CrossRef]

55) Quinlan M, Mayhew C, Bohle P (2001) The global expansion of precarious employment, work disorganization, and consequences for occupational health: placing the debate in a comparative historical context. Int J Health Serv 31, 507-36. [Medline] [CrossRef]

56) Costa G, Åkerstedt T, Nachreiner F, Baltieri F, Carvalhais J, Folkard S, Dresen MF, Gadbois C, Gartner J, Sukalo HG, Härmä M, Kandolin I, Sartori S, Silvério J (2004) Flexible working hours, health, and well-being in Europe: some considerations from a SALTSA project. Chronobiol Int 21, 831-44. [Medline] [CrossRef]

57) Benach J, Vives A, Amable M, Vanroelen C, Tarafa G, Muntaner C (2014) Precarious employment: understanding an emerging social determinant of health. Annu Rev Public Health 35, 229-53. [Medline] [CrossRef]

58) Hipple S (2001) Contingent work in the late 1990s. Mon Labor Rev 124, 3-27.

59) Henly JR, Lambert SJ (2014) Unpredictable work timing in retail jobs: implications for employee work-life conflict.
Ind Labor Relat Rev 67, 986-1016. [CrossRef]

60) Cranford CJ, Vosko LF, Zukewich N (2003) The gender of precarious employment in Canada. Relat IndustriellesIndustrial Relat 58, 454-82. [CrossRef]

61) Hannif Z, Lamm F (2005) When non-standard work becomes precarious: insights from the New Zealand call centre industry. Int Rev Manage Stud 16, 324-50.

62) Lewchuk W, Clarke M, de Wolff A (2008) Working without commitments: precarious employment and health. Work Employ Soc 22, 387-406. [CrossRef]

63) Quinlan M, Bohle P (2009) Overstretched and unreciprocated commitment: reviewing research on the occupational health and safety effects of downsizing and job insecurity. Int J Health Serv 39, 1-44. [Medline] [CrossRef]

64) De Cuyper N, De Witte H (2007) Job insecurity in temporary versus permanent workers: Associations with attitudes, well-being, and behaviour. Work Stress 21, 65-84. [CrossRef]

65) De Cuyper N, Notelaers G, De Witte H (2009) Job insecurity and employability in fixed-term contractors, agency workers, and permanent workers: associations with job satisfaction and affective organizational commitment. J Occup Health Psychol 14, 193-205. [Medline] [CrossRef]

66) Vives A, Amable M, Ferrer M, Moncada S, Llorens C, Muntaner C, Benavides FG, Benach J (2010) The Employment Precariousness Scale (EPRES): psychometric properties of a new tool for epidemiological studies among waged and salaried workers. Occup Environ Med 67, 548-55. [Medline] [CrossRef]

67) Bohle P, Pitts C, Mc Namara M, Quinlan M (under review). Powerlessness, insignificance and job insecurity: evaluating a new measure of perceived precariousness.

68) Bohle P, Quinlan M, Kennedy D, Williamson A (2004) Working hours, work-life conflict and health in precarious and "permanent" employment. Rev Saude Publica 38 Supp1, 19-25 (Journal of Public Health). [Medline] [CrossRef]

69) Bohle P, Willaby H, Quinlan M, McNamara M (2011) Flexible work in call centres: working hours, work-life conflict \& health. Appl Ergon 42, 219-24. [Medline] [CrossRef]

70) Hayman JR (2009) Flexible work arrangements: exploring the linkages between perceived usability of flexible work schedules and work/life balance. Community Work Fam 12, 327-38. [CrossRef]

71) Dembe AE, Erickson JB, Delbos RG, Banks SM (2005) The impact of overtime and long work hours on occupational injuries and illnesses: new evidence from the United States. Occup Environ Med 62, 588-97. [Medline] [CrossRef]

72) Boivin DB, Tremblay GM, James FO (2007) Working on atypical schedules. Sleep Med 8, 578-89. [Medline] [CrossRef]

73) Bohle P, Tilley AJ (1989) The impact of night work on psychological well-being. Ergonomics 32, 1089-99. 
[Medline] [CrossRef]

74) Krausz M, Sagie A, Bidermann Y (2000) Actual and preferred work schedules and scheduling control as determinants of job-related attitudes. J Vocat Behav 56, 1-11. [CrossRef]

75) McNamara M, Bohle P, Quinlan M (2011) Precarious employment, working hours, work-life conflict and health in hotel work. Appl Ergon 42, 225-32. [Medline] [CrossRef]

76) Pisarski A, Bohle P, Callan VJ (1998) Effects of coping strategies, social support and work-nonwork conflict on shift worker's health. Scand J Work Environ Health 24 Suppl 3, 141-5. [Medline]

77) Pisarski A, Brook C, Bohle P, Gallois C, Watson B, Winch S (2006) Extending a model of shift-work tolerance. Chronobiol Int 23, 1363-77. [Medline] [CrossRef]

78) Campbell I (2004) Casual work and casualisation: how does Australia compare? Labour Ind 15, 85-111. [CrossRef]

79) Nijp HH, Beckers DG, Geurts SA, Tucker P, Kompier MA (2012) Systematic review on the association between employee worktime control and work-non-work balance, health and well-being, and job-related outcomes. Scand J Work Environ Health 38, 299-313. [Medline] [CrossRef]

80) Garde AH, Albertsen K, Nabe-Nielsen K, Carneiro IG, Skotte J, Hansen SM, Lund H, Hvid H, Hansen ÅM (2012) Implementation of self-rostering (the PRIO-project): effects on working hours, recovery, and health. Scand J Work Environ Health 38, 314-26. [Medline] [CrossRef]

81) Nicol AM, Botterill JS (2004) On-call work and health: a review. Environ Health 3, 15. [Medline] [CrossRef]

82) Ferguson SA, Paterson JL, Hall SJ, Jay SM, Aisbett B (2016) On-call work: to sleep or not to sleep? It depends. Chronobiol Int 33, 678-84. [Medline] [CrossRef]

83) Paterson JL, Aisbett B, Ferguson SA (2016) Sound the alarm: health and safety risks associated with alarm response for salaried and retained metropolitan firefighters. Saf Sci 82, 174-81. [CrossRef]

84) Emmett BM, Dovey SM, Wheeler BJ (2013) After-hours on-call: the effect on paediatricians' spouses and families. J Paediatr Child Health 49, 246-50. [Medline] [CrossRef]

85) Rout U (1996) Stress among general practitioners and their spouses: a qualitative study. Br J Gen Pract 46, 157-60. [Medline]

86) Iversen L, Farmer JC, Hannaford PC (2002) Workload pressures in rural general practice: a qualitative investigation. Scand J Prim Health Care 20, 139-44. [Medline] [CrossRef]

87) New Zealand Fire Service (2001) Developing a Strategy to Nurture, Enhance, and Expand the Volunteer Fire Brigade. Research Report 23, New Zealand.

88) Janes R, Dowell A, Cormack D (2001) New Zealand rural general practitioners 1999 survey-part 1: an overview of the rural doctor workforce and their concerns. N Z Med J 114, 492-5. [Medline]

89) Gander P, Millar M, Webster C, Merry A (2008) Sleep loss and performance of anaesthesia trainees and specialists.
Chronobiol Int 25, 1077-91. [Medline] [CrossRef]

90) Bamberg E, Dettmers J, Funck H, Krähe B, Vahle-Hinz T (2012) Effects of on-call work on well-being: results of a daily survey. Appl Psychol Health Well-Being 4, 299-320. [Medline] [CrossRef]

91) Arora VM, Georgitis E, Siddique J, Vekhter B, Woodruff JN, Humphrey HJ, Meltzer DO (2008) Association of workload of on-call medical interns with on-call sleep duration, shift duration, and participation in educational activities. JAMA 300, 1146-53. [Medline] [CrossRef]

92) Smithers $F$ (1995) The pattern and effect of on call work in transplant coordinators in the United Kingdom. Int J Nurs Stud 32, 469-83. [Medline] [CrossRef]

93) Cooper CL, Rout U, Faragher B (1989) Mental health, job satisfaction, and job stress among general practitioners. BMJ 298, 366-70. [Medline] [CrossRef]

94) Saxena AD, George CF (2005) Sleep and motor performance in on-call internal medicine residents. Sleep 28, 1386-91. [Medline] [CrossRef]

95) Rose M, Manser T, Ware JC (2008) Effects of call on sleep and mood in internal medicine residents. Behav Sleep Med 6, 75-88. [Medline] [CrossRef]

96) Pilcher JJ, Coplen MK (2000) Work/rest cycles in railroad operations: effects of shorter than 24-h shift work schedules and on-call schedules on sleep. Ergonomics 43, 573-88. [Medline] [CrossRef]

97) Torsvall L, Akerstedt T (1988) Disturbed sleep while being on-call: an EEG study of ships' engineers. Sleep 11, 35-8. [Medline] [CrossRef]

98) Cowlishaw S, Evans L, McLennan J (2010) Work-family conflict and crossover in volunteer emergency service workers. Work Stress 24. [CrossRef]

99) Cowlishaw S, Evans L, McLennan J (2010) Balance between volunteer work and family roles: testing a theoretical model of work-family conflict in the volunteer emergency services. Aust J Psychol 62, 69-178. [CrossRef]

100) CFA Corporate Volunteer development project. Focus group report, 1998, East Burwood.

101) Heponiemi T, Puttonen S, Elovainio M (2014) On-call work and physicians' well-being: testing the potential mediators. Occup Med (Lond) 64, 352-7. [Medline] [CrossRef]

102) Wali SO, Qutah K, Abushanab L, Basamh R, Abushanab J, Krayem A (2013) Effect of on-call-related sleep deprivation on physicians' mood and alertness. Ann Thorac Med 8, 22-7. [Medline] [CrossRef]

103) Dinges DF, Pack F, Williams K, Gillen KA, Powell JW, Ott GE, Aptowicz C, Pack AI (1997) Cumulative sleepiness, mood disturbance, and psychomotor vigilance performance decrements during a week of sleep restricted to 4-5 hours per night. Sleep 20, 267-77. [Medline]

104) Lockley SW, Cronin JW, Evans EE, Cade BE, Lee CJ, Landrigan CP, Rothschild JM, Katz JT, Lilly CM, Stone PH, Aeschbach D Czeisler CA, Harvard Work Hours, Health and Safety Group (2004) Effect of reducing interns' weekly work hours on sleep and attentional failures. N Engl 
J Med 351, 1829-37. [Medline] [CrossRef]

105) McLennan J, Birch A, Hayes P, Cowlishaw S (2009) Maintaining volunteer firefighter numbers: adding value to the retention coin. Aust J Emerg Manag 24, 40-7.

106) Cowlishaw S, Birch A, McLennan J, Hayes P (2014) Antecedents and outcomes of volunteer work-family conflict and facilitation in Australia. Appl Psychol 63, 168-89. [CrossRef]

107) Jay SM, Paterson JL, Aisbett B, Ferguson SA (2018) No rest for the women: Understanding the impact of on-call work for women in the emergency services Chronobiology International, DOI: 10.1080/07420528.2018.1466793 https:// www.tandfonline.com/eprint/J8z8uYhZpsRksDmua9Pq/full.

108) Parkes K, Carnell SC, Farmer Rodrigues EL (2005) 'Living two lives'. Perceptions, attitudes and experiences of spouses of UK offshore workers. Community Work Fam 8, 413-37. [CrossRef]

109) Rodrigues VF, Fischer FM, Brito MJ (2001) Shift work at a modern offshore drilling rig. J Hum Ergol (Tokyo) 30, 167-72. [Medline]

110) Ross JK (2009) Offshore industry shift work-health and social considerations. Occup Med (Lond) 59, 310-5. [Medline] [CrossRef]

111) Ljoså CH, Lau B (2009) Shiftwork in the Norwegian petroleum industry: overcoming difficulties with family and social life - a cross sectional study. J Occup Med Toxicol 4, 22. [Medline] [CrossRef]

112) Ulven AJ, Omdal KA, Herløv-Nielsen H, Irgens A, Dahl E (2007) Seafarers' wives and intermittent husbands-social and psychological impact of a subgroup of Norwegian seafarers' work schedule on their families. Int Marit Health 58, 115-28. [Medline]

113) Allen TD, Johnson RC, Kiburz KM, Shockley KM (2013) Work-family conflict and flexible work arrangements: deconstructing flexibility. Person Psychol 66, 345-76. [CrossRef]

114) Casper WJ, Eby LT, Bordeaux C, Lockwood A, Lambert D (2007) A review of research methods in IO/OB work-family research. J Appl Psychol 92, 28-43. [Medline] [CrossRef]

115) Grice MM, McGovern PM, Alexander BH (2008) Flexible work arrangements and work-family conflict after childbirth. Occup Med (Lond) 58, 468-74. [Medline] [CrossRef]

116) Jansen NW, Mohren DC, van Amelsvoort LG, Janssen N, Kant I (2010) Changes in working time arrangements over time as a consequence of work-family conflict. Chronobiol Int 27, 1045-61. [Medline] [CrossRef]

117) Bielenski H, Bosch G, Wagner A (2002) Working time preferences in sixteen European Countries. Office for Official Publications of the European Communities, Luxembourg.

118) Elias N (1992) Time: An Essay. Blackwell, Oxford.

119) Almeida DM (2004) Using daily diaries to assess temporal friction between work and family. In: Crouter AC, Booth A (Eds.), Work-family challenges for low income parents and their children, 127-36, Lawrence Earlbaum Associates, Hillsdale.

120) Li J, Johnson SE, Han WJ, Andrews S, Kendall G, Strazdins L, Dockery A (2014) Parents' nonstandard work schedules and child well-being: a critical review of the literature. J Prim Prev 35, 53-73. [Medline] [CrossRef]

121) Strazdins L, Korda RJ, Lim LL, Broom DH, D'Souza RM (2004) Around-the-clock: parent work schedules and children's well-being in a 24-h economy. Soc Sci Med 59, 1517-27. [Medline] [CrossRef]

122) Strazdins L, Clements MS, Korda RJ, Broom DH, D’Souza RM (2006) Unsociable work? Nonstandard work schedules, family relationships, and children's well-being. J Marriage Fam 68, 394-410. [CrossRef]

123) Han WJ, Miller DP, Waldfogel J (2010) Parental work schedules and adolescent risky behaviors. Dev Psychol 46, 1245-67. [Medline] [CrossRef]

124) Han WJ, Waldfogel J (2007) Parental work schedules, family process, and early adolescents' risky behavior. Child Youth Serv Rev 29, 1249-66. [CrossRef]

125) Rosenbaum E, Morett CR (2009) The effect of parents' joint work schedules on infants' behavior over the first two years of life: evidence from the ECLSB. Matern Child Health J 13, 732-44. [Medline] [CrossRef]

126) Presser HB (2000) Nonstandard work schedules and marital instability. J Marriage Fam 62, 93-110. [CrossRef]

127) Davis KD, Goodman WB, Pirretti AE, Almeida DM (2008) Nonstandard Work Schedules, Perceived Family WellBeing, and Daily Stressors. J Marriage Fam 70, 991-1003. [Medline] [CrossRef]

128) Presser HB (2003) Working in a 24/7 economy (Hardcover ed.) Russell Sage Foundation, New York.

129) Barnett RC, Gareis KC (2007) Shift work, parenting behaviors, and children's socioemotional well-being-a within-family study. J Fam Issues 28, 727-48. [CrossRef]

130) Kalmijn M (1999) Father involvement in childrearing and the perceived stability of marriage. J Marriage Fam $\mathbf{6 1}$, 409-21. [CrossRef]

131) Pagnan CE, Lero DS, MacDermid Wadsworth SM (2011) It doesn't always add up: examining dual-earner couples' decision to off-shift. Community Work Fam 14, 297-316. [CrossRef]

132) Haddock SA, Zimmerman TS, Ziemba SJ, Lyness KP (2006) Practices of dual earner couples successfully balancing work and family. J Fam Econ Issues 27, 207-34. [CrossRef]

133) Mills M, Täht K (2010) Nonstandard work schedules and partnership quality. J Marriage Fam 72, 860-75. [CrossRef]

134) Carlson DS (1999) Personality and role variables as predictors of three forms of work-family conflict. J Vocat Behav 55, 236-53. [CrossRef]

135) Stoeva AZ, Chiu RK, Greenhaus JH (2002) Negative affectivity, role stress, and work-family conflict. J Vocat Behav 60, 1-16. [CrossRef]

136) Michel JS, Clark MA (2009) Has it been affect all along? A test of work-to-family and family-to-work models of 
conflict, enrichment, and satisfaction. Pers Individ Dif 47, 163-8. [CrossRef]

137) Bruck CS, Allen TD (2003) The relationship between big five traits, negative affectivity, type A behavior, and workfamily conflict. Vocat Behav 63, 457-72. [CrossRef]

138) Costa PT Jr, McCrae RR (1992) Revised NEO personality inventory (NEO-PI-R) and NEO five-factor inventory (NEO-FFI) professional manual. PAR, Odessa.

139) Wayne JH, Musisca N, Fleeson W (2004) Considering the role of personality in the work-family experience: Relationships of the big five to work-family conflict and facilitation. J Vocat Behav 64, 108-30. [CrossRef]

140) Michel JS, Clark MA, Jaramillo D (2011) The role of the Five Factor Model of personality in the perceptions of negative and positive forms of work-nonwork spillover: a meta-analytic review. J Vocat Behav 79, 191-203. [CrossRef]

141) Allen TD, Johnson RC, Saboe KN, Cho E, Dumani S, Evans S (2012) Dispositional variables and work-family conflict: a meta-analysis. J Vocat Behav 80, 17-26. [CrossRef]

142) Kinnunen U, Vermulst A, Gerris J, Makikangas A (2003) Work-family conflict and its relation to well-being: the role of personality as a moderating factor. Pers Individ Dif 35, 1669-83. [CrossRef]

143) Rantanen J, Pulkkinen L, Kinnunen U (2005) The big five personality dimensions, work-family conflict, and psychological distress. J Individ Differ 26, 155-66. [CrossRef]

144) Biggart L, Corr P, O’Brien M, Cooper N (2010) Trait emotional intelligence and work-family conflict in fathers. Pers Individ Dif 48, 911-6. [CrossRef]

145) Cohen A (2009) Individual values and the work/family interface. An examination of high tech employees in Israel. J Manag Psychol 24, 814-32. [CrossRef]

146) Innstrand ST, Langballe EM, Espnes GA, Aasland OG, Falkum E (2010) Personal vulnerability and work-home interaction: the effect of job performance-based self-esteem on work/home conflict and facilitation. Scand J Psychol 51, 480-7. [Medline] [CrossRef]

147) Andreassi JK, Thompson CA (2007) Dispositional and situational sources of control. Relative impact on workfamily conflict and positive spillover. J Manag Psychol 22, 722-40. [CrossRef]

148) Nachreiner F (1998) Individual and social determinants of shiftwork tolerance. Scand J Work Environ Health 24 Suppl
3, 35-42. [Medline]

149) Saksvik IB, Bjorvatn B, Hetland H, Sandal GM, Pallesen S (2011) Individual differences in tolerance to shift worka systematic review. Sleep Med Rev 15, 221-35. [Medline] [CrossRef]

150) Horne JA, Ostberg O (1976) A self-assessment questionnaire to determine morningness-eveningness in human circadian rhythms. Int J Chronobiol 4, 97-110. [Medline]

151) Di Milia L, Smith PA, Folkard S (2004) Refining the psychometric properties of the circadian type inventory. Pers Individ Dif 36, 1953-64. [CrossRef]

152) Di Milia L, Smith PA, Folkard S (2005) A validation of the revised circadian type inventory in a working sample. Pers Individ Dif 39, 1293-305. [CrossRef]

153) Willis TA, O’Connor DB, Smith L (2008) Investigating effort-reward imbalance and work-family conflict in relation to morningness/eveningness and shift work. Work Stress 22, 125-37. [CrossRef]

154) Iskra-Golec I (2016) Individual differences in circadian rhythm parameters and work-family relationship in shift workers. In: Iskra-Golec I, Barnes-Farrell J, Bohle P (Eds.), Social and Family Issues in Shift Work and Non Standard Working Hours, 181-202, Springer, Basel.

155) Jansen NWH, Kant IJ (2016) Reciprocal relations between working time arrangements and work-family conflict over time In: Iskra-Golec I, Barnes-Farrell J, Bohle P (Eds.), Social and family issues in shift work and non standard working hours, 59-90, Springer, Basel.

156) Grzywacz JG (2016) Shift work and its implications for everyday work and family life: a foundation and summary. In: Iskra-Golec I, Barnes-Farrell J, Bohle P (Eds.), Social and Family Issues in Shift Work and Non Standard Working Hours, Springer, Basel.

157) Tammelin M, Malinen K, Rönkä A, Verhoef M (2017) Work schedules and work-family conflict among dual earners in Finland, the Netherlands, and the United Kingdom. J Fam Issues 38, 3-24. [CrossRef]

158) Bihan B, Martin C (2004) Atypical working hours: consequences for childcare arrangements. Soc Policy Adm 38, 565-90. [CrossRef]

159) Boushey H (2006) Tag-team parenting. Center for Economic and Policy Research, Washington DC.

160) Mining Family Matters (2018) Empowering families in mining, oil \& gas. www.miningfm.com.au. Accessed May 25, 2018. 